\title{
Morphogenetic traits and biomass accumulation of Brachiaria brizantha cv. Xaraés subjected to nitrogen doses $^{1}$
}

\author{
Welton Batista Cabral ${ }^{2}$, Alexandre Lima de Souza ${ }^{2}$, Emerson Alexandrino ${ }^{3}$, Fábio Luiz \\ Buranelo Toral ${ }^{2}$, Emerson Alencar Bonelli ${ }^{2}$, Leni Rodrigues de Lima $^{2}$
}

\author{
${ }^{1}$ Financiado pela Fundação de Amparo à Pesquisa do Estado de Mato Grosso - FAPEMAT. \\ 2 Universidade Federal de Mato Grosso - UFMT. \\ ${ }^{3}$ Universidade Federal do Tocantins - UFT.
}

\begin{abstract}
The objective of this experiment was to evaluate the morphogenetic traits and biomass accumulation of

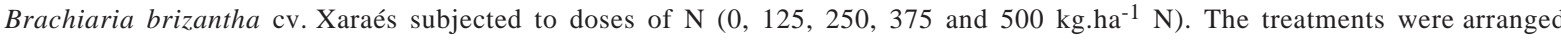
in a completely randomized design with four replications. Morphogenetic traits and biomass accumulation of dry matter (DM).ha ${ }^{-1}$ were evaluated. The results were subjected to statistical analysis by grouping the data in two periods, rainy season and throughout the year. Nitrogen doses influenced leaf appearance in the rainy season and throughout the year, with significant increase in leaf elongation during the rainy season, an increase of 56\% compared with control. During this period, maximum dose of $\mathrm{N}$ (248.1 kg.ha ${ }^{-1}$ ) produced $214.49 \mathrm{~kg}^{-h^{-1}}$.day $^{-1} \mathrm{DM}$ of leaf blade, which was $133 \%$ higher than the control. However, the higher $\mathrm{N}$ dose in the rainy season resulted in an increase of $137 \%$ in the stalk accumulation compared with non-fertilized grass; estimating maximum accumulation of salk of $84.97 \mathrm{~kg} \mathrm{ha}^{-1}$.day ${ }^{-1}$ of DM for the application of $326.2 \mathrm{~kg} . \mathrm{ha}^{-1} \mathrm{~N}$. Doses of $\mathrm{N}$ also intensified leaf senescence during the rainy season and throughout the year. The control treatment presented $32 \%$ less senescence compared with maximum $\mathrm{N}$ dose $\left(270.1 \mathrm{~kg} \cdot \mathrm{ha}^{-1} \mathrm{~N}\right)$ in the rainy season. Forage loss was estimated at $26.08 \mathrm{~kg} \mathrm{ha}^{-1}$. day ${ }^{-1} \mathrm{DM}$ at the maximum dose of $295.0 \mathrm{~kg} \cdot \mathrm{ha}^{-1} \mathrm{~N}$ for this period. All variables studied responded positively to $\mathrm{N}$ supply in the rainy season. The accumulation of biomass of the plant reached the maximum point with fertilization close to $250 \mathrm{~kg} \cdot \mathrm{ha}^{-1} \mathrm{~N}$ in the rainy season and $375 \mathrm{~kg} \cdot \mathrm{ha}^{-1} \mathrm{~N}$ throughout the year.
\end{abstract}

Key Words: fertilization, leaf appearance, morphogenesis, pastures

\section{Introduction}

Most pasture areas in Brazil are characterized as monoculture areas, based on extractive agriculture, which is supported by low-nutrient availability soils, especially $\mathrm{N}$, thus collaborating to increase degradation of the pastures, which is considered the most serious problem in bovine livestock in the country, nowadays (Macedo, 1999). However, among management strategies which can significantly alter forage productivity and contribute to the maintenance of high animal production indices is the application of fertilizers.

Among the nutrients, nitrogen is the most studied inasmuch as $\mathrm{N}$ fertilization can increase dry matter production by over $200 \%$ in relation to non-fertilized forages (Alexandrino et al., 2000). The study of morphogenetics traits and biomass acumulation in forage grasses are very important to validate management strategies, as for example nitrogen fertilization, assuring balance and sustentability for plant, animal and economic feasibility.

Despite the morphogenetic traits being genetically determined, variables such as temperaturte, nutrient supply and humidity availability in the soil can influence them (Sbrissia \& Da Silva, 2001). Morphogenetic traits can be subdivided into: leaf appearance rate; leaf elongation rate and leaf senescence rate, in addition to stalk elongation for tropical grasses (Sbrissia \& Da Silva, 2001). Leaf elongation rate of the grasses is very responsive to $\mathrm{N}$ fertilization (Gomide et al., 2006).

Brachiaria brizantha cv. Xaraés was comercially released in 2003, by Centro Nacional de Pesquisa de Gado de Corte (CNPGC) of EMBRAPA. However, its productive traits are little known, and studies to determine its requirements regarding management and soil fertility are needed. Therefore, the objective of this study was to evaluate morphogenetic traits and biomass accumulation of Brachiaria brizantha cv. Xaraés, under nitrogen doses in the condition of the southern region in Mato Grosso state.

\section{Material and Methods}

The experiment was carried out at Universidade Federal de Mato Grosso, in Campo Experimental de Forrageiras, in 
Rondonópolis, MT, from October 12, 2006 to August 23, 2007. The initial analysis of the soil presented the following result: $\mathrm{pH}$ in $\mathrm{CaCl}_{2}=4.8 ; \mathrm{P}=1.6 \mathrm{mg} \cdot \mathrm{dm}^{-3} ; \mathrm{K}=22.0 \mathrm{mg} \cdot \mathrm{dm}^{-3}$; $\mathrm{Ca}^{2+}=1.2 \mathrm{cmol}_{\mathrm{C}} \cdot \mathrm{dm}^{-3} ; \mathrm{Mg}^{2+}=1.0 \mathrm{cmol}_{\mathrm{C}} \cdot \mathrm{dm}^{-3} ; \mathrm{H}+\mathrm{Al}^{3+}=$ $3.5 \mathrm{cmol}_{\mathrm{C}} \cdot \mathrm{dm}^{-3} ; \mathrm{Al}^{3+}=0.2 \mathrm{cmol}_{\mathrm{c}} \cdot \mathrm{dm}^{-3}$; organic matter $=$ $15.3 \mathrm{~g} \cdot \mathrm{kg}^{-1}$; sum of bases $=2.3 \mathrm{cmol}_{\mathrm{c}} \cdot \mathrm{dm}^{-3}$; cation exchange capacity $=5.8 \mathrm{cmol}_{\mathrm{c}} \cdot \mathrm{dm}^{-3}$, Sum of bases $=39.0 \%$, clay $=$ $400 \mathrm{~g} \cdot \mathrm{kg}^{-1}$, silt $=100 \mathrm{~g} \cdot \mathrm{kg}^{-1}$ and total sand $=500 \mathrm{~g} \cdot \mathrm{kg}^{-1}$. Climate data (Figure 1) were collected from Estação Meteorológica do Departamento de Geografia at UFMT $400 \mathrm{~m}$ away from the experimental site.

Fertilization was carried out according to recommendation of Ribeiro et al. (1999). Phosphate fertilization was manually distributed at planting, at $100 \mathrm{~kg}$.ha ${ }^{-1}$ of $\mathrm{P}_{2} \mathrm{O}_{5}$ as superphosphate. Nitrogen and potassium fertilizations were divided into six applications: four in the rainy season, one in rainy/dry season and the last application in the dry season (Table 1). Potassium (K) was distributed at $300 \mathrm{~kg} \cdot \mathrm{ha}^{-1}$ of $\mathrm{K}_{2} \mathrm{O}$ as potassium chloride $(\mathrm{KCl})$.

Twenty plots with Xaraés grass with $12 \mathrm{~m}^{2}$ of useful area were set, and sowing was carried out in lines on December 23, 2005. Treatments consisted of five doses of N: $0,125,250,375$ and $500 \mathrm{~kg} \cdot \mathrm{ha}^{-1}$ of $\mathrm{N}$, using urea as $\mathrm{N}$ source ( $45 \%$ of $N$ ). A completely randomized experimental design with four replicates was used.

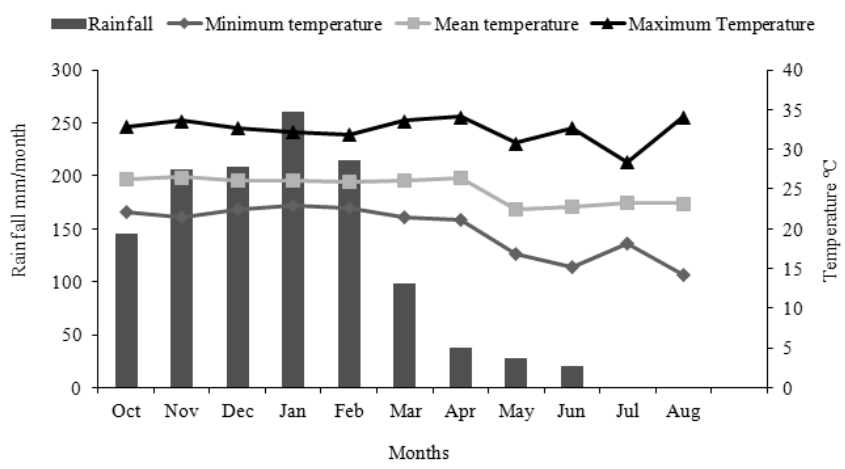

Figure 1 - Mean temperature and monthly precipitation during the experimental period (from October 2006 to August 2007).
Cutting was performed with a cleaver at $22 \mathrm{~cm}$ above soil level in all plots at every 35 days during the rainy season and at every 70 days during the dry season; seven cuttings were realized during the experimental season (Table 1).

For the evaluation of morphogenetic traits, 15 tillers per plot were identified with colored thread. Morphogenetic evaluations were performed during the sprouting period of the plants, which was at every three days during the rainy season and at every seven days during the dry season. Immediately after every cutting, new tillers were selected and identified.

The appearance of a new leaf was only characterized after each leaf was emerged and only after ligule exposition. Completed expanded leaves were measured from the ligule and the length of the emergent blade was measured from the apex to ligule of the last expanded leaf, according to Davies (1993). Culm length was measured from the soil to ligule of the last completed expanded leaf, and those measures were carried out on the first day of evaluation and after last measurement.

Length of fresh leaf blade was measured from ligule to the tip or to the end of the green part in the expanded leaves. Progressive reduction of green part and increase of senescent area characterized senescence rate and death of the tissues (Alexandrino et al., 2004). From those measures, the following aspects were calculated:

- Leaf appearance rate: obtained from the number of leaves emerged per tiller divided by the number of the days of the evaluated period - leaves.tiller ${ }^{-1}$.day ${ }^{-1}$;

- Leaf elongation rate: calculated by the sum of all leaf blade elongation per tiller divided by the number of days of the experimental period, expressed in mm.tiller-1. day ${ }^{-1}$;

- Stalk elongation rate: Sum of all elongation of stalk/ pseudostalk per tiller divided by the number of the days during the evaluation period, expressed in mm.tiller-1 ${ }^{-1}$ day ${ }^{-1}$; this measure was obtained from the soil to the height of the youngest leaf ligule.

- Leaf senescence rate: obtained by the sum of all senescent material per tiller divided by the number of days of evaluation period, expressed in mm.tiller ${ }^{-1}$. day ${ }^{-1}$;

Table 1 - Cutting intervals and distribution of $\mathrm{N}$ doses $\left(\mathrm{kg}_{\mathrm{ha}} \mathrm{h}^{-1}\right)$ over the experimental period

\begin{tabular}{|c|c|c|c|c|c|c|c|}
\hline Cutting & $1 \mathrm{st}$ & 2nd & 3rd & 4 th & 5 th & 6 th & $7 \mathrm{th}$ \\
\hline Date & $\begin{array}{c}\text { November } 16, \\
2006\end{array}$ & $\begin{array}{c}\text { December 21, } \\
2006\end{array}$ & $\begin{array}{c}\text { January 25, } \\
2007\end{array}$ & $\begin{array}{l}\text { March } 1^{\text {st }}, \\
2007\end{array}$ & $\begin{array}{l}\text { April, 4, } \\
2007\end{array}$ & $\begin{array}{c}\text { June 14, } \\
2007\end{array}$ & $\begin{array}{c}\text { August 23, } \\
2007\end{array}$ \\
\hline Dose/Interval & - & 35 & 35 & 35 & 35 & 70 & 70 \\
\hline 0 & 0 & 0 & 0 & 0 & 0 & 0 & 0 \\
\hline 125 kg.ha- ${ }^{-1} \mathrm{~N}$ & 20.83 & 20.83 & 20.83 & 20.83 & 20.83 & 20.83 & 0 \\
\hline 250 kg.ha- ${ }^{-1} \mathrm{~N}$ & 41.66 & 41.66 & 41.66 & 41.66 & 41.66 & 41.66 & 0 \\
\hline $375 \mathrm{~kg} \cdot \mathrm{ha}^{-1} \mathrm{~N}$ & 62.50 & 62.50 & 62.50 & 62.50 & 62.50 & 62.50 & 0 \\
\hline 500 kg.ha- ${ }^{-1} \mathrm{~N}$ & 83.33 & 83.33 & 83.33 & 83.33 & 83.33 & 83.33 & 0 \\
\hline
\end{tabular}


Accumulation of total dry matter, leaf blade, culm and senescent material was obtained by using the gravimetric index according to the methodology described by Alexandrino et al. (2005). One day before cutting, in the afternoon, 20 tillers.plot ${ }^{-1}$ were collected, then separated into culm, expanded leaves and expanding leaves. Next, measurement was carried out on the longitudinal axis of each component, summing up the length of each one of them at the end. After weighing of samples of leaf blade, culm and senescent material, they were dried in forcedventilation oven at $79^{\circ} \mathrm{C}$ for 72 hours.

Evaluation of tiller population density of each plot was done through sampling with a $0.15 \times 1.00$-m square placed in a representative site of the plot. All tillers in the square perimeters were counted. Leaf blade dry matter accumulation rate, culm dry matter accumulation rate and forage dry matter loss rate were obtained from the combination of morphogenetic trait, gravimetric index and tiller density, according to methodology described by Alexandrino et al. (2005).

The results were grouped according the seasons of the year; the rainy season comprised the four first cuttings (accumulated doses of 0; 83.3, 166.6; 249.9 and 333.3 kg.ha- ${ }^{-1} \mathrm{~N}$ ). The other evaluation considered the behavior of the grass throughout the year, considering all the seven cuttings with the accumulated level of complete fertilization (0; 125; 250; 375 and 500 kg.ha- $\left.{ }^{-1} \mathrm{~N}\right)$.

To evaluate the effect of the cuttings and nitrogen fertilization on morphogenetic traits of Xaraés grass during the rainy season or in the total period, analyses of covariance with repeated measures in the same experimental unity (plot) were used. Cutting effect was considered as classificatory and linear and quadratic effect of nitrogen doses were the covariables. Error was considered as a random effect and covariance structure of heterogeneous first-order autoregressive type was used to model the residual (co)variance structure. This structure was chosen because it was the one which fitted best to the available data according to -2RLL criteria (value of restrict likelihood function), AIC (Akaike information criterion) and CAIC (Consistent Akaike information criterion). An effect would be considered statistically significant when the level of significance was 0.10 , at most. Statistical analyses were carried out by using the MIXED procedure of SAS (version 8.2).

\section{Results and Discussion}

Leaf appearance rate was influenced $(\mathrm{P}<0.001)$ by the $\mathrm{N}$ doses in the rainy season, with a regression quadratic behavior (Figure 2) probably due to the action of $\mathrm{N}$ on cell multiplication in the plant apical meristem.

Nitrogen fertilization increases leaf appearance in the rainy season and consequently reduces phillochron, which is the interval between the appearance of two consecutive leaves. Maximum appearance rate was obtained with $297.49 \mathrm{~kg} . \mathrm{ha}^{-1}$ of N, totaling 0.062 leaves.tiller-1. day ${ }^{-1}$; therefore, 16.12 days were needed for the emergence of a new leaf. However, there was no reduction in leaf appearance above those doses, due to a bigger leaf blade size and pseudostalk of tillers with higher doses of $\mathrm{N}$ inasmuch as bigger pseudostalk tends to increase the interval between the emergence of two consecutive leaves, thus reducing leaf appearance rate (Skinner \& Nelson, 1995).

Alexandrino et al. (2004), studying behavior of Brachiaria brizantha cv Marandu under three doses of $\mathrm{N}$ $\left(0,20\right.$ and $40 \mathrm{mg}$. dm ${ }^{-3}$.week of $\left.\mathrm{N}\right)$ and three times of regrowth $(0,2,4,8,16,24,32$ and 48 days after cutting) found values ranging from 0.0839 to 0.1439 leaves.day ${ }^{-1}, 12$ and 7 days of phillochron, respectively, presenting linear effect to the applied doses. Similar values were found by Silva (2009), who found LApR of 0.12 leaves.day ${ }^{-1}$ when studying Brachiaria brizantha cv Marandu under three doses of $\mathrm{N}$ $\left(0,75,150\right.$ or $225 \mathrm{mg} \cdot \mathrm{dm}^{-3}$. week of $\left.\mathrm{N}\right)$

Effects of nitrogen fertilization on leaf appearance throughout the year presented linear behavior $(\mathrm{P}<0.001)$. Addition of $\mathrm{N}$ caused a positive linear increment for leaf appearance rate $\left(\hat{Y}=0.03496+0.000006941 * N ; R^{2} 0.905\right)$. estimated values ranged from 0.035 to 0.038 leaves.day $^{-1}$ for doses from 0 to $500 \mathrm{~kg} \cdot \mathrm{ha}^{-1}$ of N, 28 and 26 for formation

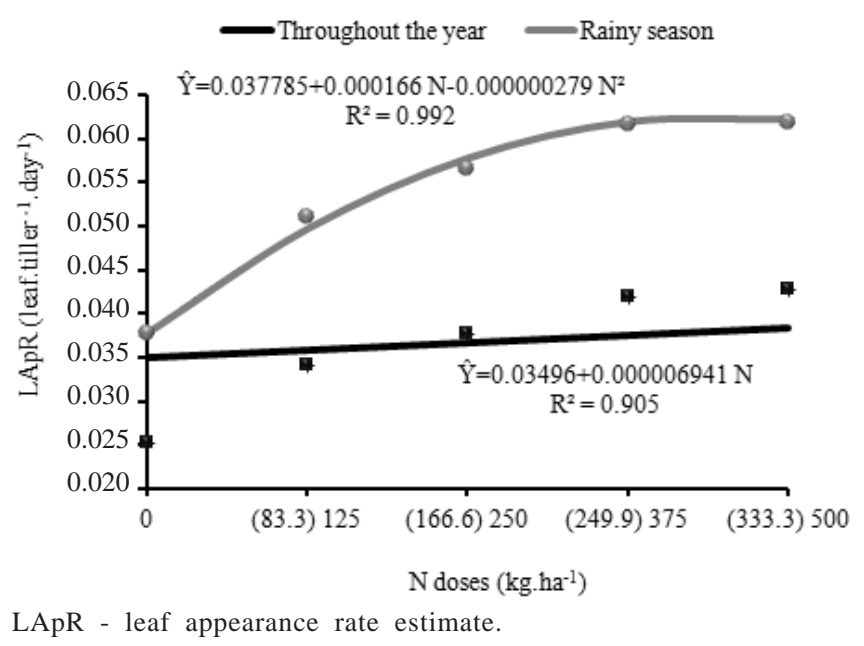

Figure 2 - Leaf appearance estimate of Xaraés grass during the rainy season and over the year, in function of $\mathrm{N}$ doses $\left(\mathrm{kg} \cdot \mathrm{ha}^{-1}\right)$. 
of a new leaf, which are numerically inferior to those recorded for the rainy season, due to the amplitude of responses between treatments are rather lower over the year, supposedly due to limitation of climate factors during the dry season.

Those magnitude of values for rainy season and throughout the year are below those verified by Martuscello et al. (2005), who found values of leaf appearance ranging from 0.096 to 0.12 leaves.day ${ }^{-1}$, for doses from 0 to $120 \mathrm{mg} \cdot \mathrm{dm}^{-3}$ of $\mathrm{N}$ with Brachiaria brizantha cv. Xaraés grown in pots. Studies with Xaraés grass are still incipient; therefore, there is little comparative basis for this and other traits.

Leaf appearance rate (Figure 3) was influenced by nitrogen fertilization during the rainy season $(\mathrm{P}<0.001)$ and evaluation year period $(\mathrm{P}<0.01)$.

Quadratic effect of $\mathrm{N}$ doses on leaf appearance was observed, estimating a maximum value from 46.46 to $32.38 \mathrm{~mm}$ tiller $^{-1}$.day $^{-1}$ with doses of 275.9 and $41.1 \mathrm{~kg}$.ha ${ }^{-1}$ of $\mathrm{N}$ for the rainy season and throughout the year, respectively. Segatto (2009), studying Aruana grass under $\mathrm{N}$ doses $\left(0,125,250,375\right.$ and $500 \mathrm{~kg}^{-h^{-1}}$ de $\left.\mathrm{N}\right)$ found maximum value of $32.73 \mathrm{~mm}$.tiller ${ }^{-1}$. day ${ }^{-1}$ for the estimated dose of $414.3 \mathrm{~kg} \cdot \mathrm{ha}^{-1}$ of $\mathrm{N}$, resulting in an increment of $35.5 \%$ in the leaf elongation when compared with the control.

Nitrogen fertilization resulted in an increment of 56 and 26\% in leaf elongation when compared with Xaraés grass not fertilized with $\mathrm{N}$ in the rainy season and over the year, respectively, corresponding to values of 0.10 and $0.0027 \mathrm{~mm}$.tiller ${ }^{-1}$.day ${ }^{-1}$ of leaf blade for each $\mathrm{kg}$ of applied $\mathrm{N}$, respectively.

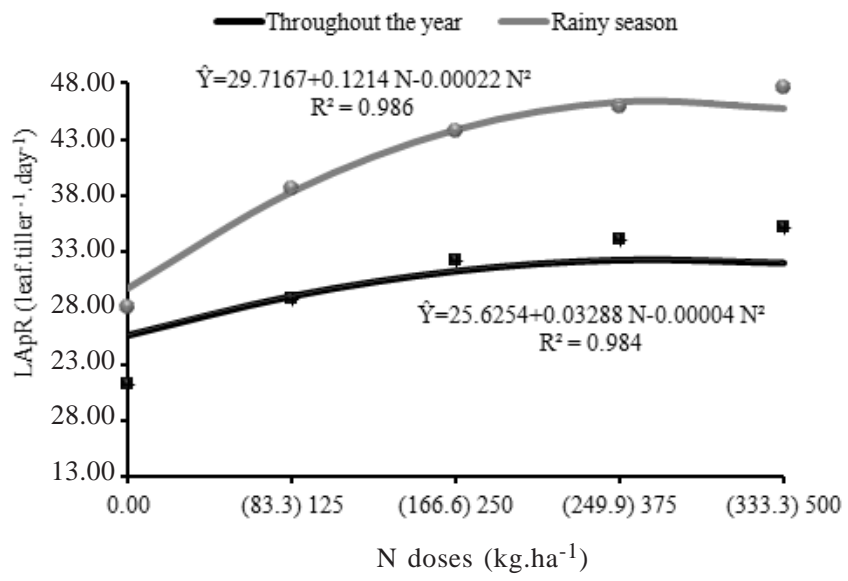

LApR - leaf appearance rate estimate.

Figure 3 - Leaf appearance rate estimate of Xaraés during the rainy season and throughout the year, in function of $\mathrm{N}$ doses $\left(\mathrm{kg} \cdot \mathrm{ha}^{-1}\right)$.
Those data are similar to the ones found by Martuscello et al. (2005), who found an increase of $37 \%$ in the leaf elongation for dose of $120 \mathrm{mg} \cdot \mathrm{dm}^{-3}$ of $\mathrm{N}$ in relation to the lack of nitrogen fertilization for Xaraés grass grown in pots.

Other studies evaluating effects of $\mathrm{N}$ on leaf elongation rate also presented similar results (Gastal \& Nelson, 1994; Alexandrino et al., 2000). According to Volenec \& Nelson (1994), the increase in leaf elongation rate, caused by nitrogen fertilization is due to a greater cell production, with little effect on the final size of the cell or on epidermal cell elongation rate.

Quadratic effect $(\mathrm{P}<0.0001)$ of $\mathrm{N}$ doses was also observed on tiller population density for both periods of evaluation, with estimation of a maximum value of 113 and 110 tillers. $0.15 \mathrm{~m}^{-2}$ for doses of 270 and $401 \mathrm{~kg}^{-h^{-1}}$ of $\mathrm{N}$, respectively. It also observed a quadratic effect $(\mathrm{P}<0.0001)$ of $\mathrm{N}$ doses on tiller population density for both periods of evaluation, estimating a maximum value of 113 and 110 tillers. $0.15 \mathrm{~m}^{-2}$ for doses of 270 and $401 \mathrm{~kg}^{-h^{-1}}$ of $\mathrm{N}$, respectively (Figure 4).

Tiller density increased by 89 and $87 \%$ in relation to non-fertilized grass, for the rainy season and throughout the year, respectively (Figure 4). For the non-fertilized plots, tiller density of Xaraés grass throughout the year was limited and constant, an average of 58.9 tillers $.0 .15 \mathrm{~m}^{-2}$.

Use efficiency of nitrogen fertilization for the two evaluated periods was 0.19 tiller. $0.15 \mathrm{~m}^{-2}\left(270 \mathrm{~kg} . \mathrm{ha}^{-1} \mathrm{~N}\right)$ and 0.12 tiller. $0.15 \mathrm{~m}^{-2}\left(401 \mathrm{~kg} \cdot \mathrm{ha}^{-1} \mathrm{~N}\right)$ for each $\mathrm{kg} \mathrm{N}$ used, in the rainy season and throughout the year, respectively.

After peak points of the two evaluated seasons, tiller density decreased possibly because the higher doses had

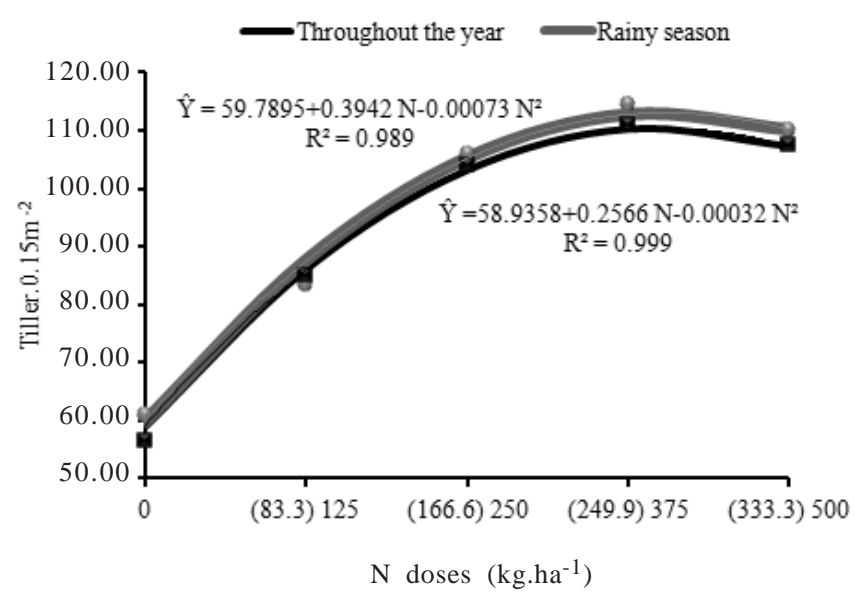

Figure 4 - Population density estimate of Xaraés grass during the rainy season and over the year in function of $\mathrm{N}$ doses $\left(\mathrm{kg}^{\mathrm{ha}} \mathrm{a}^{-1}\right)$. 
increased leaf elongation, allowing plant communities to reach a greater height and leaf area index, creating competition for light among tillers, decreasing luminosity on the base of the tillers, which is a factor known for interfering in tillering capacity of the tropical grasses. Many results available in the literature point a decrease in the population of tillers as pastures are kept higher (Hodgson, 1985; Sbrissia \& da Silva, 2001; Sbrissia, 2004).

As leaf elongation and appearance and tiller population increased, a quadratic and positive effect $(\mathrm{P}<0.0001)$ of $\mathrm{N}$ doses on leaf blade dry matter accumulation was observed, estimating a maximum value of $214.49 \mathrm{~kg} \cdot \mathrm{ha}^{-1}$. day $^{-1}$ of DM for a dose of $248.1 \mathrm{~kg}^{-h^{-1}}$ of $\mathrm{N}$, which was $133 \%$ higher than the control (Figure 5). Leaf production efficiency was $0.493 \mathrm{~kg} \cdot \mathrm{ha}^{-1} \cdot \mathrm{dia}^{-1}$ of DM for each kg of $\mathrm{N}$ applied.

With the increase from $248.1 \mathrm{~kg}$.ha-1 of $\mathrm{N}$ to $333.33 \mathrm{~kg}^{-h^{-1}}$ of $\mathrm{N}$, there was a reduction in leaf blade production, probably due to environmental limitations (soil and weather) and genetic factors of the plant, to efficiently respond to the increase of $\mathrm{N}$ doses. Another hypothesis to explain the efficiency drop at higher $\mathrm{N}$ levels is that $\mathrm{pH}$ in water has a negative linear relationship with $\mathrm{N}$ levels $(\mathrm{pH}$ in water $=$ $5.80-0.0057 * \mathrm{~N}, \mathrm{R}^{2}=0.61$, Barak et al., 1997), and maybe at the highest $\mathrm{N}$ level, the acidification process was favored by increase of $\mathrm{NH}_{4}{ }^{+}$ion concentration before the nitrification process, which may have partially limited intake of nutrients, as for example $\mathrm{N}$, phosphorus, calcium and potassium or maybe it caused increase on availability of aluminum, which causes a toxic effect on the roots of the plants.

By evaluating leaf blade accumulation throughout the year, a quadratic behavior $(\mathrm{P}<0.001)$ to the $\mathrm{N}$ doses can be observed, with an accumulation peak of $161.38 \mathrm{~kg} \cdot \mathrm{ha}^{-1}$. day ${ }^{-1}$

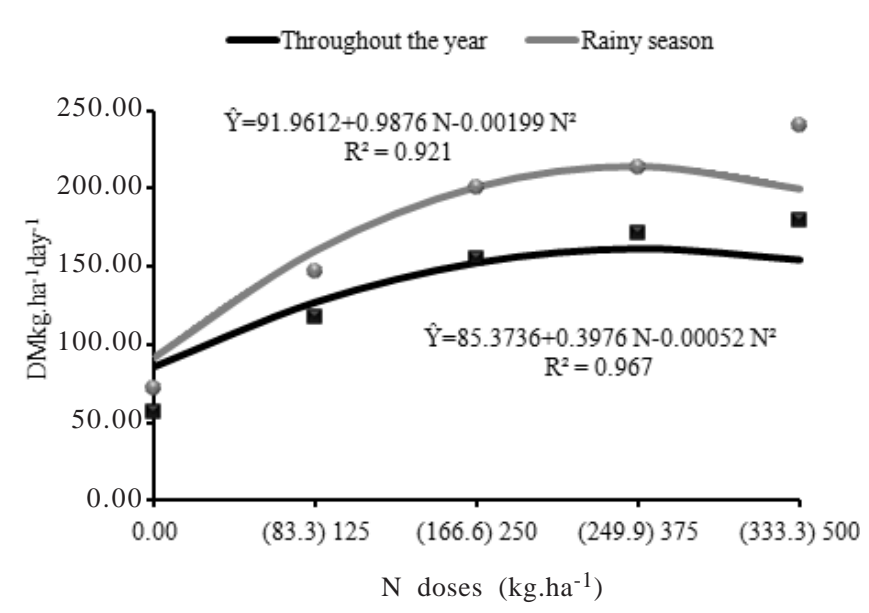

Figure 5 - Leaf blade dry matter (DM) accumulation rate estimate of Xaraés grass during the rainy season and throughout the year in function of $\mathrm{N}$ doses $\left(\mathrm{kg} \cdot \mathrm{ha}^{-1}\right)$. of DM, when $382.3 \mathrm{~kg} . \mathrm{ha}^{-1}$ of $\mathrm{N}$ was applied. Considering that the peak in relation to the plots which were not fertilized with nitrogen, an increase by $89 \%$ in leaf blade accumulation was observed, with $\mathrm{N}$ efficiency use of $0.198 \mathrm{~kg} \cdot \mathrm{ha}^{-1}$.day ${ }^{-1}$ of DM for each kg of $\mathrm{N}$ applied.

Stalk elongation rate was quadratically influenced $(\mathrm{P}<0.001)$ by nitrogen fertilization during the rainy season and throughout the year (Figure 6), with maximum values of $3.44 \mathrm{~mm}$.tiller ${ }^{-1}$.day ${ }^{-1}$ for the dose of $380.3 \mathrm{~kg} \cdot \mathrm{ha}^{-1}$ of $\mathrm{N}$ for the year evaluation period. Fertilization resulted in an increase of $21 \%$ in stalk elongation when compared with non-fertilized grass throughout the year. Stalk elongation in the rainy season ranged from 2.86 to $6.76 \mathrm{~mm}_{\text {.tiller }}{ }^{-1}$.day ${ }^{-1}$ for doses from 0 to $333.3 \mathrm{~kg} \cdot \mathrm{ha}^{-1}$ of N, respectively. Maximum point for the rainy season was not obtained, in which maximum applied dose of $\mathrm{N}$ was below $333.3 \mathrm{~kg} \cdot \mathrm{ha}^{-1}$ of $\mathrm{N}$, and the maximum efficiency would be obtained with the dose of $459.5 \mathrm{~kg} . \mathrm{ha}^{-1}$ of N.

Stalk elongation presented undesirable effect on forage quality by reducing blade-stalk relationship, and consequently a drop of the nutritional value of the forage. Parsons (1988) said the importance of controlling stalk production in the pasture, claiming that its presence could reduce the efficiency of the system in two manners: by limiting capacity of forage harvest by the animal or by reducing its nutritional value. The greatest stalk accumulation for the greatest doses of $\mathrm{N}$ verified is justified by the greater production of leaf blade and by the physiologic activity of the plant under non-limiting production conditions, which increase leaf tissue production flow, causing a shading of the low leaves and basal buds, stimulating stalk elongation by the plant (Sbrissia \& Da Silva, 2001).

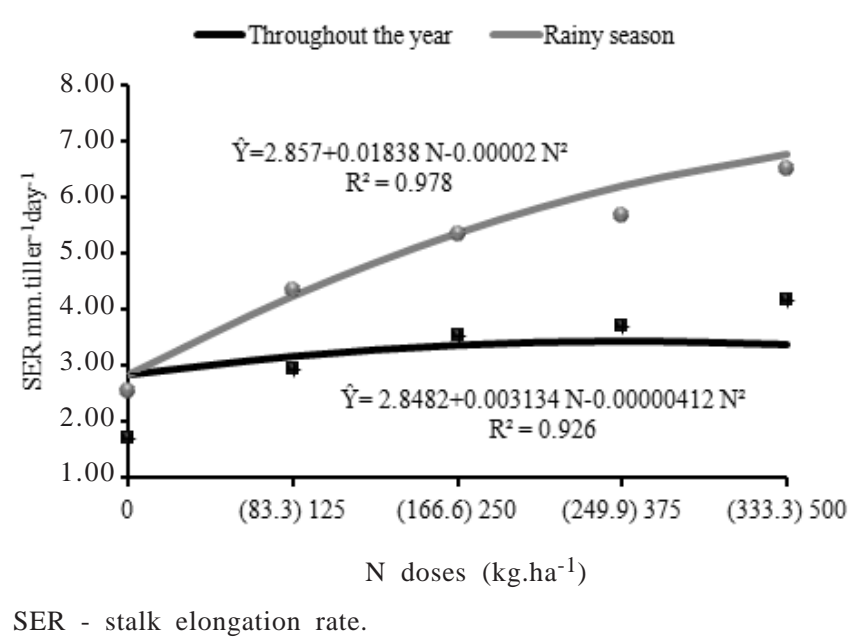

Figure 6 - Stalk elongation rate estimate of Xaraés grass during the rainy season and throughout the year in function of $\mathrm{N}$ doses $\left(\mathrm{kg} \cdot \mathrm{ha}^{-1}\right)$. 
By separating the effects of nitrogen fertilization during the rainy season into linear and quadratic effect (Figure 7), quadratic effect $(\mathrm{P}<0.10)$ of $\mathrm{N}$ doses was observed on stalk accumulation, with estimation of a maximum production of $84.97 \mathrm{~kg} \cdot \mathrm{ha}^{-1}$. day $^{-1}$ of DM for application of $326.2 \mathrm{~kg} \cdot \mathrm{ha}^{-1}$ of $\mathrm{N}$, from which productive efficiency of $0.189 \mathrm{~kg} \cdot \mathrm{ha}^{-1}$. day ${ }^{-1}$ of DM for each kg of applied $\mathrm{N}$ was estimated. Although stalk development favors increase of DM production, it can present negative effects on use and quality of the produced forage (Santos, 2003).

By evaluating stalk accumulation throughout the year, there was no effect $(\mathrm{P}>0.10)$ of the $\mathrm{N}$ doses on this trait. When the three last cutting were considered, climate conditions were unfavorable to growth limited stalk expansion in the dry season, therefore, there was no significant response of $\mathrm{N}$ doses.

Leaf senescence rate (Figure 8) was influenced by nitrogen fertilization in the rainy season $(\mathrm{P}<0.15)$ and throughout the year $(\mathrm{P}<0.10)$.

A quadratic behavior for leaf senescence during the rainy season was observed, estimating a maximum value of 6.55 mm.tiller ${ }^{-1}$.day $^{-1}$ for the dose of $270.1 \mathrm{~kg}^{-h^{-1}}$ of N$^{\mathrm{N}}$, but for the year period, data fitted for the linear model, estimating a value of $4.91 \mathrm{~mm}$.tiller ${ }^{-1}$.day $^{-1}$ for the dose of $500 \mathrm{~kg}$.ha ${ }^{-1}$ of $\mathrm{N}$. It could observed that for the control treatment, leaf senescence rate was $32 \%$ lower in relation to that verified with the greatest dose of $\mathrm{N}$ applied during the rainy season and $9 \%$ throughout the year.

Senescence rate for year evaluation period ranged from 4.47 to $4.91 \mathrm{~mm}$.tiller $^{-1}$. day ${ }^{-1}$ when submitted to fertilization with 0 to $500 \mathrm{~kg} \cdot \mathrm{ha}^{-1}$ of $\mathrm{N}$, respectively. The values found are close to the ones found by Martuscello et al. (2005)

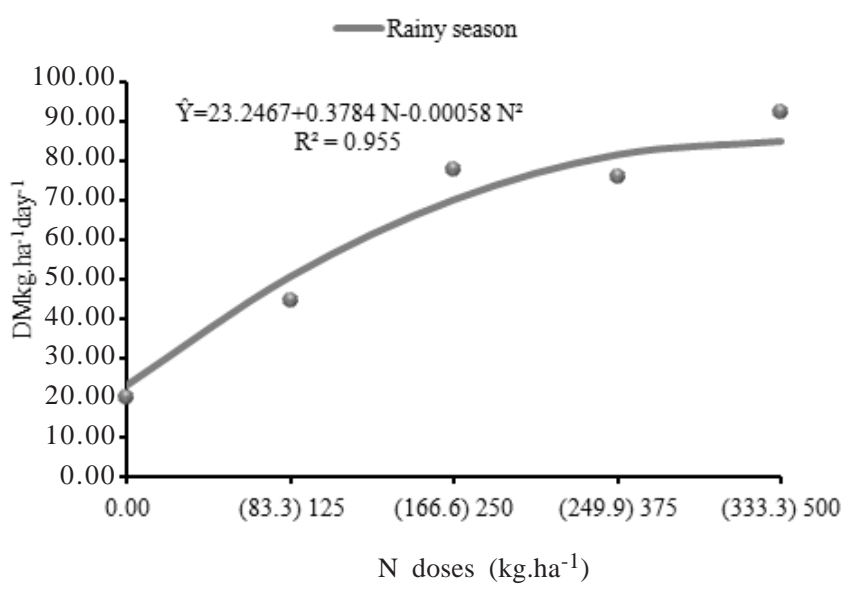

Figure 7 - Estimate of stalk dry matter (DM) accumulation rate of Xaraés grass during the rainy season, in function of $\mathrm{N}$ doses $\left(\mathrm{kg} \cdot \mathrm{ha}^{-1}\right)$.

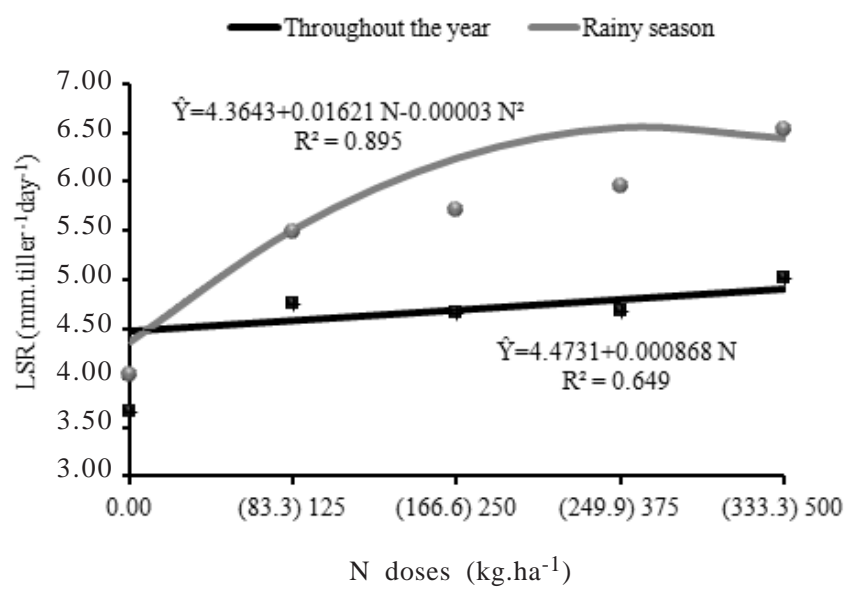

LSR - leaf senescence rate estimate.

Figure 8 - Leaf senescence rate estimate of Xaraés grass during the rainy season and throughout the year, in function of $\mathrm{N}$ doses $\left(\mathrm{kg} \cdot \mathrm{ha}^{-1}\right)$.

for Xaraés grass, in which leaf senescence ranged from 3.6 mm.tiller ${ }^{-1}$.day ${ }^{-1}$ for plants without $\mathrm{N}$ fertilization and harvested with five leaves to $7.7 \mathrm{~mm}$.tiller ${ }^{-1}$. day ${ }^{-1}$ for plants which received $120 \mathrm{mg}^{-\mathrm{dm}^{-3}}$ of $\mathrm{N}$ and were harvested with two leaves for cultivation in pots.

Senescence increased in leaf blades of Xaraés grass when it was submitted to increasing doses of $\mathrm{N}$ because there was an intense cell multiplication under non-limiting production conditions, accelerating tissue deaths. Mazzanti \& Lemaire (1994) say that, in general, there is an increase in senescence rate under high $\mathrm{N}$ availability because of the competition for light, determined by the increase in leaf elongation rate and by the longer final size of the leaves.

An effect $(\mathrm{P}<0.10)$ of $\mathrm{N}$ for the evaluated seasons was also verified on forage loss rate, estimating a maximum value of 26.08 and $23.14 \mathrm{~kg} \mathrm{ha}^{-1}$. $\mathrm{dia}^{-1}$ of DM for the dose of 295 and $487 \mathrm{~kg}^{2} \mathrm{ha}^{-1}$ of $\mathrm{N}$ for the rainy season and year evaluation period (Figure 9).

Many works, as those of Wilson \& Mannetje (1978) and Clark (1980), present reports in which forage loss rate occurs more rapidly in plants under favorable growth conditions than in those with some kind of stress (Barbosa, 2007).

Senescence can be accelerated by action of the environment factors or it can occur spontaneously at the end of leaf lifespan or tiller lifespan. Therefore, although the rainy season may be the best period for production of green material it is also the period of the year which causes the highest senescence rate of vegetal tissue when fertilized with N. Thus, management practices in this period must promote the increase of pasture efficiency, at the ideal moment through adjustments in frequency and intensity so that losses by senescence in Xaraés grass are minimized. 


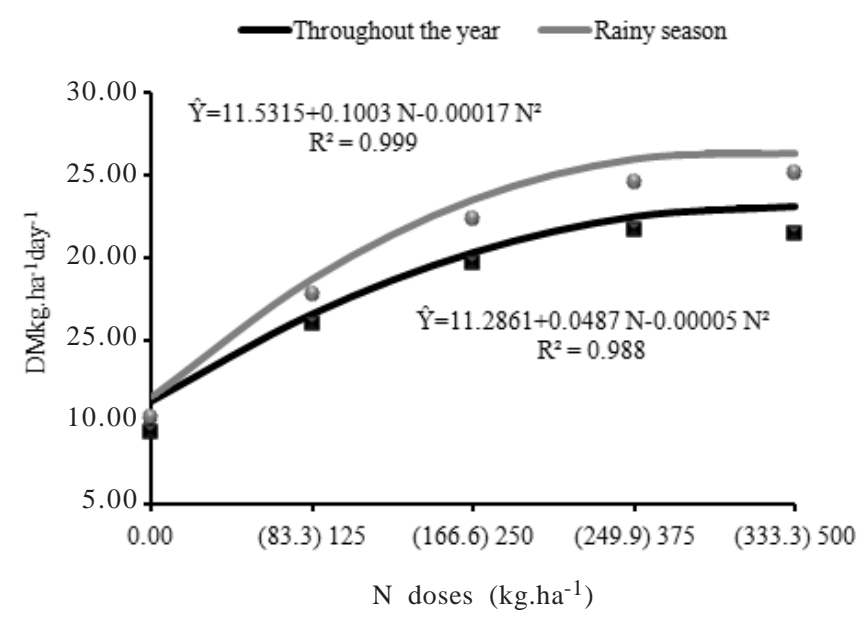

DM - dry matter.

Figure 9 - Forage loss rate estimate of Xaraés grass during the rainy season and in the year period, in function of $\mathrm{N}$ doses $\left(\mathrm{kg}_{\mathrm{ha}} \mathrm{h}^{-1}\right)$.

\section{Conclusions}

Nitrogen fertilization positively increases rates of leaf elongation and appearance and stalk elongation rates of Xaraés grass, particularly during the rainy season, and a dose of $250 \mathrm{~kg} \cdot \mathrm{ha}^{-1}$ in this season is recommended. Senescence process of this forage is accelerated as higher doses of nitrogen are applied, so a rest period inferior to 35 days is necessary.

\section{References}

ALEXANDRINO, E.; NASCIMENTO JÚNIOR, D.; MOSQUIM, P.R., et al. Efeito de três doses de nitrogênio sobre características da Brachiaria brizantha cv. Marandu após o corte de uniformização. In: REUNIÃO ANUAL DA SOCIDADE BRASILEIRA DE ZOOTECNIA, 37., 2000, Viçosa, MG. Anais... Viçosa, MG: SBZ, 2000. (CD-ROM).

ALEXANDRINO E.; NASCIMENTO JÚNIOR, D.; MOSQUIM, P.R. et al. Características morfogênicas e estruturais na rebrotação da Brachiaria brizantha cv. Marandu submetida a três doses de nitrogênio. Revista Brasileira de Zootecnia, v.33, n.6, p.1372-1379, 2004.

ALEXANDRINO, E.; GOMIDE, C.A.M; CÂNDIDO, J.D.C. et al. Período de descanso, características estruturais do dossel e ganho de peso vivo de novilhos em pastagem de Capim-Mombaça sob lotação intermitente. Revista Brasileira de Zootecnia, v.34, n.6, p.2174-2184, 2005.

BARAK, P.; JOBE, B.O.; KRUEGER, A.R. et al. Effects of long term soil acidification due to nitrogen fertilizer inputs in Wisconsin. Plant and Soil, n.197, p.61-69, 1997.

BARBOSA, R.A.; NASCIMENTO JÚNIOR, D.; EUCLIDES, V.P.B. et al. Capim - tanzânia submetido a combinações entre intensidade e freqüência de pastejo. Pesquisa Agropecuária Brasileira, v.42, n.3, p.329-340, 2007.
CLARK, S.C. Reproductive e vagetative performance in two winter annual grasses, Catapodium rigidum (L.) C.E. Hubbard and C. maximum (L.) C.E. Hubbard. 2. Leaf-demography and its relationship to the production of cariopses. New Phytology, v.84, p.79-93, 1980.

DAVIES, A. Tissue turnover in the sward. In: DAVIES, A.; BAKER, R.D.; GRANT, S.A. et al. (Eds.). Sward measurement handbook. 2.ed. Reading: British Grassland Society, 1993. p.183-216.

GASTAL, F.; NELSON, C.J. Nitrogen use within the growing leaf blade of tall fescue. Plant Physiology, v.105, p.191-197, 1994.

GOMIDE, C.A.M; GOMIDE, J.A.; PACIULLO, D.S.C. Morfogênese como ferramenta para o manejo de pastagens. In: REUNIÃO ANUAL DA SOCIEDADE BRASILEIRA DE ZOOTECNIA, 43. João Pessoa, 2006. Anais... João Pessoa: SBZ, 2006. p.554-579.

HODGSON, J. The control of herbage intake in the grazing ruminant. Proceedings of the Nutrition Society, v.44, p.339-346, 1985.

MACEDO, M.C.M. Degradação de pastagens: conceitos e métodos de recuperação. In: SIMPÓSIO SUSTENTABILIDADE DA PECUÁRIA DE LEITE NO BRASIL, 1999, Goiânia. Anais... Juiz de Fora: Embrapa Gado de Leite; Goiânia: Serrana Nutrição Animal, 1999. p.137-150.

MARTUSCELLO, J.A.; FONSECA, D.M.; NASCIMENTO JÚNIOR, D. et al. Características morfogênicas e estruturais do capim-xaraés submetido à adubação nitrogenada e desfolhação. Revista Brasileira de Zootecnia, v.34, n.5, p.1475-1482, 2005.

MAZZANTI, A.; LEMAIRE, G. Effect of nitrogen fertilization on the herbage production of tall fescue swards grazed continuously with sheep. 2. Consumption and efficiency of herbage utilization. Grass and Forage Science, v.49, n.2, p.352-359, 1994.

PARSONS, A.J. The effects of season and management on the growth of grass swards. In: JONES, M.B.; LAZENBY, A. (Eds.) The grass crop: the physiological basis of production. London: Chapman e Hall, 1988. p.129-177.

RIBEIRO, A.C.; GUIMARÃES, P.T.G.; ALVARES, V.H. Recomendações para o uso de corretivos e fertilizantes em Minas Gerais. $5^{a}$ Aproximação. Viçosa, MG, 1999. 359p.

SANTOS, P.M.; BALSALOBRE, M.A.A.; CORSI, M. Morphogenetic characteristics and management of Tanzania grass. Pesquisa Agropecuária Brasileira, v.38, n.8, p.991-997, 2003.

SBRISSIA, A.F.; DA SILVA, S.C. O ecossistema de pastagens e a produção animal. In: MATTOS, W.R.S. (Ed.) A produção animal na visão dos brasileiros. Piracicaba: SBZ, 2001. p.731-754.

SBRISSIA, A.F. Morfogênese, dinâmica do perfilhamento e do acúmulo de forragem em pastos de capim-Marandu sob lotação contínua. 2004. 171f. Tese (Doutorado em Agronomia - Ciência Animal e Pastagens) - Escola Superior de Agricultura "Luiz de Queiroz", Piracicaba.

SEGATTO, C.E. Doses de nitrogênio em capim-aruana: Características morfogênicas, estruturais e produção de forragem. 2009. 106f. Dissertação (Mestrado em Ciência Animal) - Universidade Federal de Mato Grosso, Cuiabá.

SILVA, C.C.F; BONOMO, P.; PIRES, A.J.V. et al. Características morfogênicas e estruturais de duas espécies de braquiária adubadas com diferentes doses de nitrogênio. Revista Brasileira de Zootecnia, v.38, n.4, p.657-661, 2009.

SKINNER, R.H.; NELSON, C.J. Elongation of the grass leaf and its relationship phillochron. Crop Science, v.35, n.1, p.4-10, 1995.

VOLENEC, J.J.; NELSON, C.J. Carbohydrate metabolism in leaf meristems of tall fescue. II. Relationship to leaf elongation rates modified by nitrogen fertilization. Plant physiology, v.74, p.595-600, 1994.

WILSON, J.R.; MANNETJE, L. Senescence and digestibility and carbohydrate content of buffel grass and green panic leaves in swards. Australian Journal Agricultural Research, v.29, n.3, p.503-516, 1978. 